\title{
TV/Series
}

$2 \mid 2012$

Les séries télévisées dans le monde : Échanges, déplacements et transpositions

\section{Canon Trouble: Intertextuality and Subversion in Queer as Folk}

\section{Ronan Ludot-Vlasak}

\section{(2) OpenEdition \\ Journals}

Electronic version

URL: http://journals.openedition.org/tvseries/1479

DOI: $10.4000 /$ tvseries. 1479

ISSN: 2266-0909

Publisher

GRIC - Groupe de recherche Identités et Cultures

Electronic reference

Ronan Ludot-Vlasak, "Canon Trouble: Intertextuality and Subversion in Queer as Folk», TV/Series

[Online], 2 | 2012, Online since 01 November 2012, connection on 01 May 2019. URL : http://

journals.openedition.org/tvseries/1479; DOI : 10.4000/tvseries.1479

\section{(c) (i) (9)}

TV/Series est mis à disposition selon les termes de la licence Creative Commons Attribution - Pas d'Utilisation Commerciale - Pas de Modification 4.0 International. 


\title{
Canon Trouble: \\ Intertextuality and Subversion in Queer as Folk
}

Ronan LUDOT-VLASAK

\begin{abstract}
Drawing on gender and queer theory, but also on cultural materialism, this article explores some intertextual references - mainly to Shakespeare and John Keats - at work in the American TV series Queer as Folk. The show recycles canonical works or figures, but considerably reconfigures them. Not only are these references pervaded with overt sexual innuendoes, but they also challenge the literary canon "from within," regenerate it and invite us to revisit these works - to re-read them against the grain - and to explore their potential queerness.
\end{abstract}

$\mathrm{A}$

dapted from a British mini-series broadcast on Channel 4 in 1999, the American version of Queer as Folk aired on Showtime and Showcase from 2000 until 2005. Set in Pittsburgh, most of its plot revolves around six gay men: Brian, a gorgeous high-flying advertising executive unwilling to compromise his queer values and allegedly the best gay lover in the whole city; Justin, a 17-year-old teenager in Season 1 who engages in a dysfunctional relationship with Brian, who intends to turn him into the "best homosexual" ever; Michael - Brian's best friend - who owns his comic-book store and meets Ben, an HIV-positive academic specialized in queer studies; Ted, an accountant who actually looks like an accountant, and who then starts his own porn website "jerkatwork.net;" and Emmett, the most eccentric of the gang, whose many jobs in the five seasons include working as a shopkeeper, a naked maid, a porn star and a successful party planner. The plot also features Lindsay and Melanie, who get married in Season 2, Deb - Mike's larger-than-life mother - and her brother Vic. The series marked a major change in the depiction of gays and lesbians in TV shows, not because most of the scenes are set on Liberty Avenue - the heart of Pittsburgh's gay district - but because of its graphic representations of gay and lesbian sexuality. It does not avoid some stereotypes about gays (tops vs. bottoms being the most blatant one), yet it offers a clearly unapologetic vision of homosexuality and, on the whole, "ultimately positions itself as anti-assimilationist (at least as far as sex is concerned) ${ }^{1}$." Although, in the pilot episode, Michael says in voice-over that "it's all about sex," the show also addresses major political issues - same-sex marriage, prostitution, social inequalities, religion and politics -, as well as cultural ones by

${ }^{1}$ Rebecca Clare Beirne, "Embattled Sex: Rise of the Right and Victory of the Queer in Queer as Folk," in The New Queer Aesthetic of Television. Essays on Recent Programming, ed. James R. Keller and Leslie Stratyner, Jefferson, London, McFarland \& Company, 2006, p. 44 [p. 43-58]. 
blurring the line between highbrow and lowbrow ${ }^{2}$ and alluding, in many episodes, to major works of the western literary canon.

Be they critics, academics or amateurs, some who celebrate "great" Literature (with a capital L), which is of course "not for an age, but for all time," tend to regard TV series as a form of lowbrow culture of no interest, brainwashing our students and contributing to the dumbing-down of cultural standards. In such a view, popular forms of literature as well as visual and TV culture borrowing from the works of the literary canon - mostly dead white males, yet not always straight may only parody, or adulterate the "true" meaning of these works. Do TV series have so little to say about Shakespeare, Keats or Dickens? If we follow such an ideological line, great works would generate meaning while TV series would only aim at generating profit. If one must admit that TV shows have commercial imperatives, so did most of our canonical writers. Furthermore, being a commercial product targeting a certain kind of audience does not mean that a work is not able to question literature and the legitimacy of the literary canon. One question that is seldom asked by scholars is what these discursive and visual apparatuses have to say about the canon. This is precisely the vantage point from which I will explore some intertextual transactions at work in Queer as Folk.

The fact that the series quotes from and reinvents major figures of literary history does not trivialize canonical works, nor is it a way for the show to find some form of artistic legitimacy, since it constantly blurs the line between "great" art and popular culture. Drawing on gender and queer theory, but also on cultural materialism, I will propose another approach to the issue. In this paper, I intend to explore the ability of a TV series like Queer as Folk to question and regenerate the literary canon by inviting us to revisit it and look at it from a different angle. In other terms, instead of looking at intertextuality in queer culture, I will rather delve into the potential queerness of intertextuality.

I would like to start this paper with a few preliminary remarks which will inform my critical inquiry. One first element is that a TV series or any form of popular culture may have something to say about canonical literary works. Thus, the question may not be: what does a canonical text lose when it is appropriated by a TV series, but: what does it gain in the whole process? How is its meaning complexified? What do such appropriations tell us about this work? How do they prompt us to revisit the works they quote from or recuperate? How do they question the formation and perpetuation of the literary canon? In

${ }^{2}$ This is particularly visible in the relationship between Mike and Ben, the former knowing everything about American comics and the latter being an academic who teaches seminars on homoeroticism in Willa Cather's fiction. 
other terms, I won't see these intertextual practices as a form of loss or degradation. On the contrary, I will try to explore what new forms of meaning and reading they may generate.

Another point I would like to make is the relevance of queer and gender theory to explore concepts such as canonicity and intertextuality. Like gender, it might be argued that the canon operates through "a repetition and a ritual, which achieves its effects through its naturalization in the context of a [textual] body," to paraphrase Judith Butler3. Quoting from the canon contributes to "this process of materialization that stabilizes over time to produce the effect of boundary, fixity ${ }^{4}$." Yet one might also wonder if intertextuality and "citationality5" may not have more subversive effects and may not challenge the canon from within. Asserting that Shakespeare or any major writer is "not for an age, but for all time" may thus be accounted for as a fairly essentialist vision - to use the terminology of gender theory - of the canon. Conversely, one may argue that the meaning of canonical texts is a cultural construct and a process subject to change as well as a performance involving individual readers and competing ideological models - be they dominant, negotiated or radical.

Queer as Folk recycles canonical works or figures, but considerably remodels them. Strange as it may seem, one finds Hamletian and Keatsian echoes in two of the characters. Yet, unlike their models, they are determined to survive and to struggle with the world. This process of rewriting simultaneously addresses both literary and political or ideological issues.

Mike's uncle, Vic, is in many respects a post-modern Keatsian avatar, yet one who survives, first literally, then metaphorically. The consumptive Romantic poet enamored of Fanny Brawne is here metamorphosed into a middle-aged HIV-positive gay man who was not taught how to dissect a body like the poet, but how to carve meat, as he was trained as a cook. Before the beginning of the show's general plot (the event is referred to on several occasions by Mike and his mother), he was hospitalized and most doctors predicted that he had no more than a few weeks to live. Following in Keats's footsteps, he decided to spend all his savings on a trip to Rome with his sister ("He went there to die," Michael says): to consume his savings before he finally consummates himself - see Rome and die. Yet, unlike Keats, he survives and lives for another four years as if this final journey had brought him back to life. At the beginning of Season 4, he dies of a

3 Judith Butler, Gender Trouble. Feminism and the Subversion of Identity, New York, Routledge, 1999 [1990], p. xv.

4 Judith Butler, Bodies That Matter. On the Discursive Limits of Sex, New York, London, Routledge, 1993, p. 9.

5 "Citationality" and the "citational" dimension of "the law that produces material effects" are addressed in Butler's introduction to Bodies That Matter, especially p. 12. 
heart attack ironically caused by his medication. While the poet's famous epitaph ("Here lies one whose name was writ in water") is "theatrically staged as a fluid, evanescent metaphor of poetic identity ${ }^{6}$," Vic's tomb is, according to his sister Deb, "solid [...], hard, smooth" (4.9). As Mike says on several occasions in the show, quoting from Gloria Gaynor, "despite everything, we will survive."

Just after Vic passes away, most of the characters meet at Deb's house. During a conversation involving Hunter (Mike and Ben's adoptive son) and Rodney (Vic's partner), Emmett underlines how tragic this untimely death is:

BRIAN. What the fuck happened?

BEN. His heart. The doctor said his cholesterol was sky-high from the meds he was taking.

MIKE. No warning. Nothing.

HUNTER. I thought the meds were supposed to keep you alive, not kill you.

BEN. Doesn't always work that way.

RODNEY. I thought we'd have more time than this.

EMMETT. You guys should have been together a lot longer. It's tragic.

BRIAN. Hamlet's tragic. Platform shoes are tragic. (4.6)

While Brian's second statement is typical of his sharp and witty cynicism, we may see in the first one a refusal to trivialize the concept of tragedy, which is almost systematically used by the general public or the media when an untimely death occurs. Brian's words unexpectedly take a metatextual turn and point to the fact that tragedy belongs to the world of literature, not that of everyday life. Yet stating that death caused by AIDS is not a tragedy does not minimize the impact of the disease and has major political implications. If AIDS is no tragedy, it cannot be regarded as God's curse on gay men and there might be a way out. This reference to Hamlet simultaneously points to the fictional status of tragedy and reads as a political statement, thus illustrating one of the key axioms of cultural materialism, i.e. that "culture is political7."

Surprisingly enough, Brian himself is associated with the figure of Hamlet on several occasions. In the final episode of Season 1, Justin is bashed by one of his schoolmates after dancing with Brian at his school prom in front of all the students. Mike, who has temporarily moved to Portland, comes back after a month, expecting to find Brian dejected and shut up in his state-of-the-art loft. Instead, "the most fabulous fag in Pittsburgh" is having casual sex in the backroom of

6 Caroline Bertonèche, "Here lies one whose name was writ in water': Keats and de Kooning or the abstract expressionist vision of a Romantic epitaph," Revue LISA/LISA ejournal [Online], Vol.5, No. 2, 2007, online since January $1^{\text {st }}$, 2007, http://lisa.revues.org/1223, consulted September $26^{\text {th }}, 2011$.

7 Alan Sinfield, Cultural Politics - Queer Readings, Philadelphia, University of Pennsylvania Press, 1994, p. viii. 
Babylon - the characters' favorite club. When Mike eventually meets him there, the latter asks him: "So who told you I was here, Rosencrantz or Guildenstern?" (2.1). Brian is referring ironically to Ted and Emmett, who told Mike where he might find his friend. One of the effects of this sharp reply is that it also indirectly makes him a Hamletian figure. In the fourth season, he has been drinking at Babylon and quotes from Hamlet's famous lines: "Is it better to suffer the slings and arrows of outrageous fortune, or take arms against a sea of troubles?" (4.5). His Hamletian dilemma is the following: Justin, who has joined a gay self-defense group, is willing to avenge himself on the man who bashed him in Season 1 and Brian does not know whether he should interfere. It is worth noticing that these Hamletian echoes are related to violent events involving Justin, and which may ultimately result in Brian losing his young lover (on the contrary, references to Keats - be they associated with Vic or Brian - always point to the ideas of survival and vital energy). Visually speaking, emphasis is laid on the contrast between the energy of the dancers performing under the spotlights (see Plate 1) and Brian sitting in a dimly-lit corner of the club (see Plate 2).

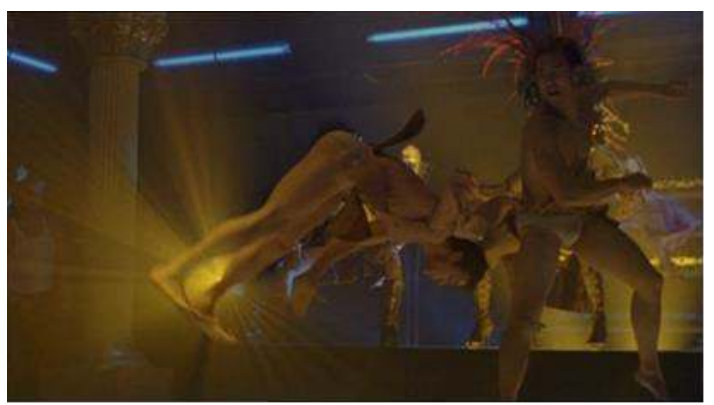

Plate 1

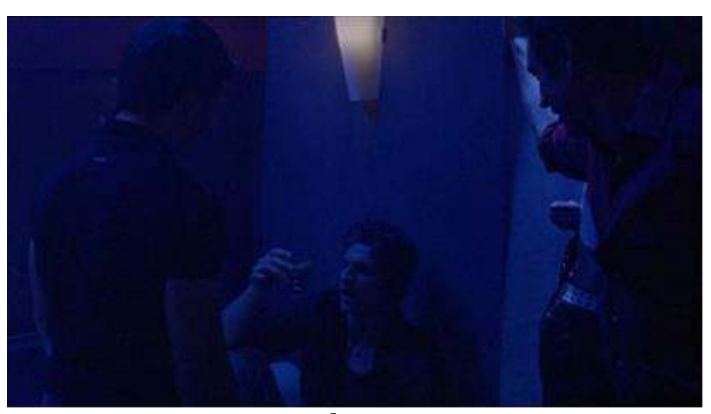

Plate 2 
Yet do these references make Brian a new Hamlet? I would argue instead that the gay King of Babylon is an inverted and queered version of Shakespeare's undecided Prince and his Romantic avatars. His thoughtful posture in the club might be reminiscent of Shakespearean clichés (the skull often held by Hamlet in performances of the play being ironically replaced by a glass of whisky), but Brian is hardly a procrastinator. He is instead a successful queer Hamlet - in a not-that-gay-friendly capitalist America - who is what he performs and adamantly refuses to apologize, let alone to repent, for what he is to his bigot of a mother or to God. A compulsive decision maker who intends to remain on top - both in bed and at work -, his main driving force is action. He sells all his belongings to fund a campaign against a homophobic Republican candidate or rides 300 miles on a bike for a charity although he was on radiation a few weeks before. As for his flesh, it is never "too solid" (or "too sullied") and is quite unlikely to "resolve itself into a dew," as Hamlet says, but rather into sweat. He is also quite unlikely to be haunted by the memory of his alcoholic father. When the latter dies (1.19), Brian keeps his bowling ball - his father's only hobby along with heavy drinking -, but he eventually decides to get rid of it. At the end of the episode, he puts on the old man's bowling shirt, drives to a quiet neighborhood with Mike, gets out of the car and throws the ball as far as he can, thus evacuating the ghost of his recently-deceased father ${ }^{8}$.

References to canonical texts in Queer as Folk are thus deliberately distorted, reconfigured, but also pervaded with overt sexual innuendoes. When Emmett decides to join a Christian group called "See the Light" (seeing the light meaning "becoming straight"), Michael and Ted are ready to resort to any means to convince him to give up his project. They decide to ask Zack O Tool, Emmett's favorite porn star, to pay him a visit in his apartment. This impressive bodybuilt man who is a high-performance sex engine of sorts is playing a leading part in a play entitled Twelve Horny Men, but he is about to make what he calls "his Shakespearean début in Coriol-Anus," the hyphen turning Rome's homosocial political world into a gay orgy.

Another example involving Brian and John Keats is a case in point. After he recovers from testicular cancer, Brian suffers from erectile dysfunction, probably the worst ordeal possible for Liberty Avenue's most efficient sex-machine. He confronts his alcoholic and fundamentalist mother, who thinks her son is going to burn in Hell for copulating with men (4.10). She wants him to give up his sinful and unnatural lifestyle, but if God performs a miracle at this very moment, it is quite different from the one she expected, since Brian has an

8 The only dead character who haunts Brian is Vic. He is visited by his ghost during his sleep on two occasions when he is treated against cancer (Season 4, episodes 8 and 9). 
erection a couple of hours later. Being once again able to perform in bed or in backrooms, he rushes to Babylon to celebrate his recovery with Justin. He starts quoting from Endymion ("Is that a thing of beauty?") and Justin completes the famous line ("A joy forever!"). The two lovers then leave the dance-floor and head to the backroom of the club. Although this Keatsian line is often interpreted as a celebration of artistic beauty and creation, "the thing of beauty" is here a physical and palpable object, and the joy it creates is no longer the sublimation of bodily sensations, but bodily pleasure itself. As Caroline Bertonèche argues, "the perfection of Endymion's opening lines [in this episode] is anatomical9" - a fairly Keatsian experience in a way since the poet received a medical training before he turned to poetry.

What is surprising about two handsome and horny gay men discussing literary issues in a gay club on a Saturday evening? That gay men yearning for passionate sex may be willing - and may be learned enough - to get any interest in literature? That such discussions may take place in a night club with dance or techno music playing loud? In any case, they challenge the status of major canonical works as sacred relics whose eternal truths are not to be questioned. Yet I believe that there is more than meets the eye here.

Let's start with Coriolanus. Alan Sinfield reminds us that when Tim Luscombe and his London Gay Theatre decided to "perform Shakespeare with a distinctive slant - playing up 'the gay relationship between Horatio and Hamlet" for instance, tabloids were only too happy to come up with parodic titles of Shakespeare plays such as The Fairy Wives of Windsor, or Tight-Ass Andronicus ${ }^{10}$. Thus, for an openly gay-friendly show written by openly gay men, turning the title of one of Shakespeare's Roman plays into a sexual pun is a way to recuperate, subvert and appropriate earlier jokes on Shakespeare made by conservative and hardly gay-friendly mass media. It also points to the sexual issues raised by Coriolanus and invites us to explore the textual cracks of the play. Indeed, the Roman hero considers that submitting to the people by showing them his wounds in order to become consul would turn him into some "harlot" or emasculated boy:

Away, my disposition; and possess me

Some harlot's spirit! My throat of war be turned,

Which choired with my drum, into a pipe

Small as an eunuch or the virgin voice

That babies lull asleep! (Coriolanus, 3.2.111-115 ${ }^{11}$ )

\footnotetext{
9 Caroline Bertonèche, "Filming Poetry: Keats on Screen," paper given at the "Romantic Adaptations Conference" held in London on March 25-26, 2011.

${ }^{10}$ Sinfield, p. 9.

${ }^{11}$ William Shakespeare, The Tragedy of Coriolanus, in The Norton Shakespeare, ed. Stephen Greenblatt, New York, London, W. W. Norton \& Company, 1997, p. 2837-2838.
} 
In Act 5, Volumnia's influence on her son leads Aufidius to call Coriolanus "a boy of tears" (5.6.104) who "[a]t a few drops of women's rheum, which are/ As cheap as lies, [...] sold the blood and labour/ Of our great action" (5.6.45-47 ${ }^{12}$. The images of prostitution, emasculation and penetration which pervade the play thus question Coriolanus's masculine ethos and testify to the haunting fear of the hero that he might turn into a boy - some kind of "Ganymede-like figure ${ }^{13}$." In Sinfield's words:

Sodomy was a continual threat around the edges of male bonding. It is not a matter of whether Coriolanus and Aufidius fucked, but of the text being unable, and perhaps unwilling, to dispel the ghost of such an inference ${ }^{14}$.

Significantly, Zack O Tool's porn impersonation of the Roman hero will no doubt evacuate such spectral fear since the actor is clearly known to be a top unlikely to become anyone's "boy".

Justin and Brian's Keatsian verbal game is also more complex than it may look at first sight. The scene turns sex - both genitals and sexual intercourse - into "a thing of beauty," but one might argue that it also makes the experience of beauty a form of sexual - orgasmic pleasure. This is all the more significant as Brian was confronted in the previous episodes with the possibility of never recovering from his disease. After Brian experienced his own contingency as a lesser mortal, passionate sex in a backroom and drugs enabled him and Justin to turn finitude into an intense moment of ecstasy - actually in both senses of the term. Brian and Justin go through a queer Keatsian experience where sex is a way to escape from and overcome the passing of time, not because of its reproductive function, but because it is a form of intense pleasure anchored in the present time - some kind of pure energy to be consummated in the most gratuitous way. Brian's sex is thus a form of recreation for two reasons: not only is it an artifact the product of reconstructive surgery -, but it also enables the couple to consummate their passion. The backroom actually proves to be a place for inspiration in an episode from Season 2, when Brian finds the slogan of a new campaign for a steak house ("Eat the meat") while being given oral sex at Babylon (2.18).

Another issue at work in the scene is that it invites us to read or rather re-read - Keats's works against the grain. In the 1990s, several scholars "sexualized" Keats and focused on gender issues in his poetry ${ }^{15}$ and in the early 2000 s, emphasis was laid more on anatomical

${ }^{12}$ Ibid., p. 2868

${ }^{13}$ Sinfield, p. 18

${ }_{14}$ Sinfield, p. 19.

15 Geraldine Friedman, "The Erotics of Interpretation in Keats's Ode on a Grecian Urn: Pursuing the Feminine," Studies in Romanticism, Vol. 32, No. 2, 1993, p. 225-43; Ann K. Mellor, Romanticism and Gender, New York, Oxford University Press, 1993; Susan J. 
issues $^{16}$. These academic works have thus challenged more ethereal and sometimes disembodied - interpretations of the poet by bringing bodily issues to the fore. More than being mere sexual puns, these forms of intertextual recuperation point to the sexual potential of the canonical works they quote from and are in line with recent academic contributions made by queer studies and cultural materialism. In this respect, they undermine the idea according to which so-called lowbrow cultural products have no relevance whatsoever to address the literary canon. The canonical texts revisited in Queer as Folk thus release "all the[ir] potential significance" which they did not "contain within [their] project" 17 .

Ultimately, I think one may read Queer as Folk's intertextual games and re-creations in the light of a short scene in which Brian asserts once again his own singularity. One evening, while playing pool at Woody's, their favorite bar on Liberty Avenue, Emmett, Mike and Ted talk about the fundraising event organized by Angels Over Pittsburgh, a gay charity supporting HIV-positive men in need (2.13). They are trying to find a celebrity to sponsor the event and Emmett mentions the name of Divina Devore, Pittsburgh's most famous drag queen. It turns out that Brian does not know anything about this imaginary queer icon - and he could not care less. When Emmett asks him: "What kind of homosexual are you?" the latter answers: "The kind that fucks men." By defining homosexuality as something you perform ("to fuck"), not only does Brian dismiss essentialist views of homosexuality, but he also challenges post-1870 definitions of the term $^{18}$. If this scene addresses the issue of a gay identity and of a gay culture and seems to have little to do with my topic, the particular form of questioning it raises is also relevant to other fields; it may, for instance, account for the intertextual transactions at work in the series and shows the ability as well as the desire of queerness "to wash across whole cultures ${ }^{19}$ ". The canon is not necessarily a normative corpus jeopardizing the emergence of alternative forms of culture constituting as many responses to its domination. Instead, the question may be how

Wolfson, "Feminising Keats," in Critical Essays on John Keats, ed. Hermione De Almeida, Boston, G.K. Hall, 1990, p. 317-356; Susan J. Wolfson, "Keats and the Manhood of the Poet," European Romantic Review, Vol. 6, No. 1, 1995, p. 1-37.

16 J. Najarian, Victorian Keats, Manliness, Sexuality and Desire, London, Palgrave, 2003; S. Wootton, Consuming Keats: Nineteenth-Century Representations in Art and Literature, London, Palgrave Macmillan, 2005.

${ }_{17}$ Sinfield, p. 36

18 I am here referring to Foucault, who considers that our modern definition of the homosexual "as a species" dates back to 1870 , with the publication of an article by Carl Westphal on "contrary sexual feeling" (Michel Foucault, Histoire de la Sexualité I. La volonté de savoir, Paris, Gallimard, 1976, p. 59).

19 Eve Kosofsky Sedgwick, Epistemology of the Closet, Berkeley, Los Angeles, London, University of California Press, 2008 [First published in 1990], p. 93. 
to use this very corpus. If one follows a constructionist approach, one might envisage the canon not as a stable entity, but as a form of praxis which simultaneously shapes and transforms it.

Stating that it merely subverts the foundations on which the canon rests does not, in my view, account for the complexity of the show's use of the literary canon. More subversive is the idea that such attitudes encourage us to re-read it against the grain - and thus to generate new meanings through the act of reading - and prompt us to explore what the dominant ideology which sustains the canon may hush up in the texts it celebrates - in other terms, to explore its potential queerness. The show relocates the canon where it is hardly to be expected and thus challenges the artificial border between straight and gay culture as well as some interpretative traditions. It allows it to broaden its scope, to operate in unusual or new spaces - be they social, cultural or ideological. It literally takes canonical texts out of a straight and often dusty - closet where they are kept most of the time. This heterogeneous clash ("une puissance hétérogène," to use Rancière's words ${ }^{20}$ ) is not just the incongruous conflation of two hermetical spheres, but a fertile encounter opening up new perspectives on the literary canon. In Eve Sedgwick's words:

No one can know in advance where the limits of a gay-centered inquiry are to be drawn, or where a gay theorizing of and through even the hegemonic high culture of the Euro-American tradition may need or be able to lead ${ }^{21}$.

This may be the most subversive aspect of Queer as Folk's intertextual recreations. The latter do not "dislodge the master-canon from its empirical centrality ${ }^{22}$ " by promoting alternative counter canons, but invite us to explore and use the canon differently. In other terms, Queer as Folk challenges the canon from within. It unlocks, displaces and reconfigures it, and by doing so, reveals its ability to regenerate itself, to survive, "like the fittest organisms in the natural world [...] and to cope with a changed cultural environment ${ }^{23}$." "Despite everything, we will survive."

\footnotetext{
${ }^{20}$ Jacques Rancière, Le Partage du sensible. Esthétique et politique, Paris, La Fabriqueéditions, 2000, p. 31.

${ }^{21}$ Sedgwick, p. 53

${ }^{22}$ Ibid., p. 50

23 Jonathan Bate, The Genius of Shakespeare, New York, Oxford, Oxford University Press, 1998 , p. 316.
} 


\section{Bibliography}

BATE Jonathan, The Genius of Shakespeare, New York, Oxford, Oxford University Press, 1998.

BEIRNE Rebecca Clare, "Embattled Sex: Rise of the Right and Victory of the Queer in Queer as Folk," in The New Queer Aesthetic of Television. Essays on Recent Programming, ed. James R. Keller and Leslie Stratyner, Jefferson, London, McFarland \& Company, 2006, p. 43-58.

BERTONÈCHE Caroline, "'Here lies one whose name was writ in water': Keats and de Kooning or the abstract expressionist vision of a Romantic epitaph," Revue LISA/LISA e-journal [Online], Vol. 5, No. 2, 2007, online since January $1^{\text {st }}$, 2007, http://lisa.revues.org/1223, consulted September $26^{\text {th }}, 2011$.

Bertonèche Caroline, "Filming Poetry: Keats on Screen,” paper given at the "Romantic Adaptations Conference" held in London on March 25-26, 2011.

ButLer Judith, Gender Trouble. Feminism and the Subversion of Identity, New York, Routledge, 1999 [1990].

Butler Judith, Bodies That Matter. On the Discursive Limits of Sex, New York, London, Routledge, 1993.

Foucault Michel, Histoire de la Sexualité I. La volonté de savoir, Paris, Gallimard, 1976.

FRIEDMAN Geraldine, "The Erotics of Interpretation in Keats's Ode on a Grecian Urn: Pursuing the Feminine," Studies in Romanticism, Vol. 32, No. 2, 1993, p. 225-43.

MELlor Ann K., Romanticism and Gender, New York, Oxford University Press, 1993.

NAJARIAn J., Victorian Keats, Manliness, Sexuality and Desire, London, Palgrave, 2003.

RanciÈRE Jacques, Le Partage du sensible. Esthétique et politique, Paris, La Fabrique-éditions, 2000.

SEDGWICK Eve Kosofsky, Epistemology of the Closet, Berkeley, Los Angeles, London, University of California Press, 2008 [1990]. 
SHAKESPEARE William, The Tragedy of Coriolanus, in The Norton Shakespeare, ed. Stephen Greenblatt, New York, London, W. W. Norton \& Company, 1997.

Sinfield Alan, Cultural Politics - Queer Readings, Philadelphia, University of Pennsylvania Press, 1994.

Wolfson Susan J., "Feminising Keats," in Critical Essays on John Keats, ed. Hermione De Almeida, Boston, G.K. Hall, 1990, p. 317-356.

"Keats and the Manhood of the Poet," European Romantic Review, Vol. 6, No. 1, 1995, p. 1-37.

Wootton S., Consuming Keats: Nineteenth-Century Representations in Art and Literature, London, Palgrave Macmillan, 2005. 